\title{
Optimization Analysis of No Winding Composite Floor Pipe Truss and Its Matching Degree
}

\author{
Lei $\mathrm{LI}^{1, \mathrm{a}}$, Li-Ting CHEN ${ }^{1}$, Song-Jin WU ${ }^{1}$ \\ ${ }^{1}$ School of civil engineering, Chang'an University, No.161 Chang An Road Xi'an, Shan Xi province, \\ 710064, China \\ a1158662558@qq.com
}

Keywords: No Winding, Composite Floor Pipe Truss, Mechanical Performance, Matching Degree.

\begin{abstract}
With the focuses on cross section of pipe truss, depth span ratio, width height ratio, thickness of concrete slab and concrete strength, this paper uses finite element software ABAQUS to analyze failure mode, ductility and ultimate bearing capacity of no winding composite floor pipe truss, puts forward the matching degree $\eta$ of such truss, so as to provide a basis for engineer design.
\end{abstract}

\section{Introduction}

Composite pipe truss structure is a new structural type based on the composite space truss, depending on the coaction of pipe truss and concrete slab. This structure has its advantages of light weight, high rigidity and low price, as well as larger integral stiffness and bearing capacity with equal steel quantity. According to Article 2.0.8 of Code of Research on Composite Floor of Steel Truss and Concrete for the floor and roof in a multi-story building with a span not greater than $40 \mathrm{~m}$ and $60 \mathrm{~m}$ respectively, the structure of composite space grids could be used where upper chords are substituted by concrete slab. This paper will be focused on this new no winding composite floor pipe truss structure. As both domestic and foreign study show the mechanical performance superiority of this structure, it is of magnificent theory significance and widespread application value to give it a further study.

\section{Model Analysis}

\section{Parameters Setting and Feasibility Analysis of Model}

Based on the characteristics of the composite floor pipe truss this article uses finite element software ABAQUS in the aspects of cross section of pipe truss, depth span ratio, width height ratio, thickness of concrete slab and concrete strength to analyze mechanical performance of the no winding composite floor pipe truss. 67 models wear built, the span length is $24 \mathrm{~m}$; depth span ratio selected $0.67,0.8$ and 1 ; width height ratio selected 1/12, 1/14 and 1/16; thickness of concrete slab selected $140 \mathrm{~mm}, 180 \mathrm{~mm}, 200 \mathrm{~mm}$ and $220 \mathrm{~mm}$; concrete strength selected C30, C40, C50 and C60; cross section of pipe truss selected according to the order from small to large is D, A, E, F, B, G, C.

Feasibility analysis of model: Fig. 1 shows the load-deflection curves of composite pipe truss model, theoretical curve agrees well with simulated curve in ABAQUS. The theoretical value is slightly less than the calculated value, because the theoretical analysis ignored the shear deformation. This proves the practicability of model.

\section{Analysis of Failure Mode}

There are two failure modes of no winding composite pipe truss: ductile failure and brittle failure. Which failure mode will happen depends on the matching degree between the thickness of concrete slab, its strength, cross section of the members of pipe truss and its steel strength. When the two matches are well, the yielding of the lower chord and the crushing of the concrete slab happen at the same time. This failure mode is portentous and is ductile failure. When the concrete slab is too weak, the crushing of concrete slab happens before the yielding of the lower steel chord, this failure mode is brittle, thus not allowed in design. When the strength of the concrete slab is too high, the 
concrete in compression zone dose not reach it maximum capacity while the lower chord fails in tension. Because this failure mode does not make full play to concrete strength, resulting in the waste of concrete, hence not allowed in design.

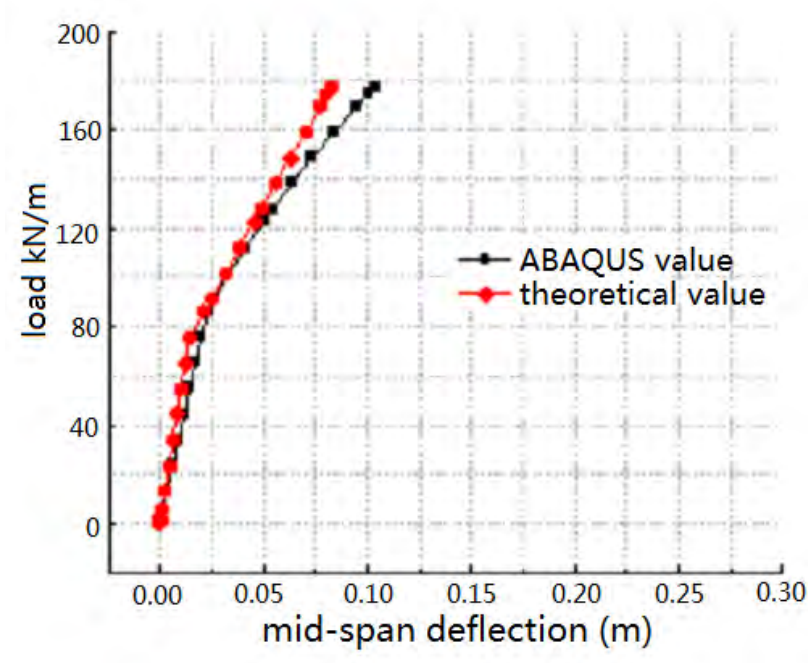

Fig. 1 Verification of Load and Mid-span

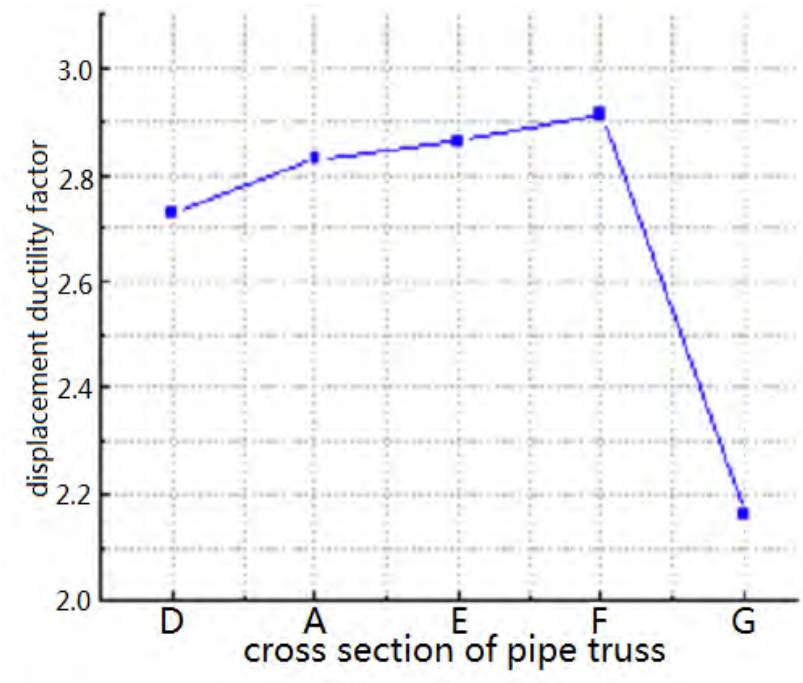

Fig. 2 Displacement Ductility Factor in Different Cross Sections of Pipe Truss

\section{Analysis of Ductility}

According to Fig. 2, the displacement ductility factor grows slowly first, after reaching the peak, it goes down rapidly. It can be obtained from the model analysis that the closer the crushing load of concrete and the breaking load of the lower steel chord, the nearer displacement ductility factor and the peak. So the ductility of the composite pipe truss is rely on the thickness of concrete slab, its concrete strength, the cross section and steel strength of pipe truss.

Analysis of Ductility Study on Influencing Factors of the Ultimate Bearing Capacity. With consideration of five aspects, i.e., the cross section of pipe truss, depth span ratio, width height ratio, thickness of concrete slab and concrete strength, this section analyzes the ultimate bearing capacity of the composite pipe truss.

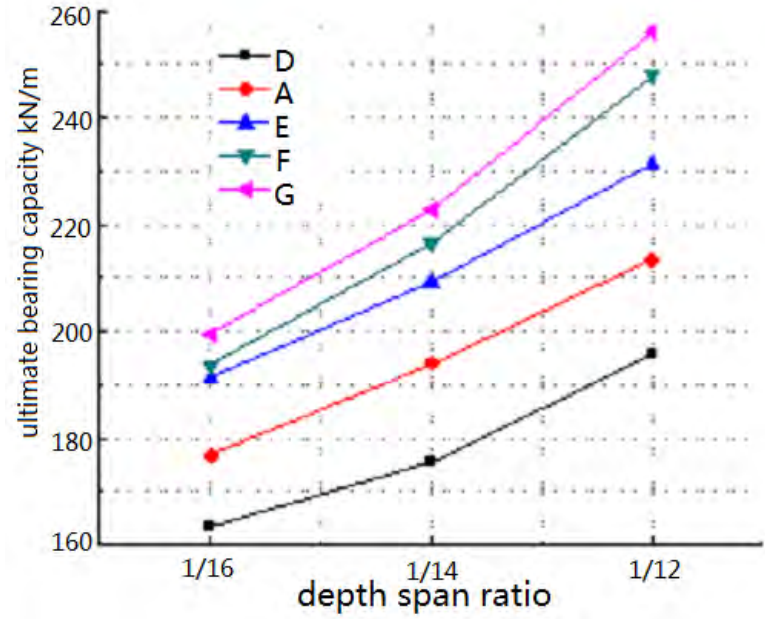

Fig. 3 Ultimate Bearing Capacity in Different Cross Sections of Pipe Truss

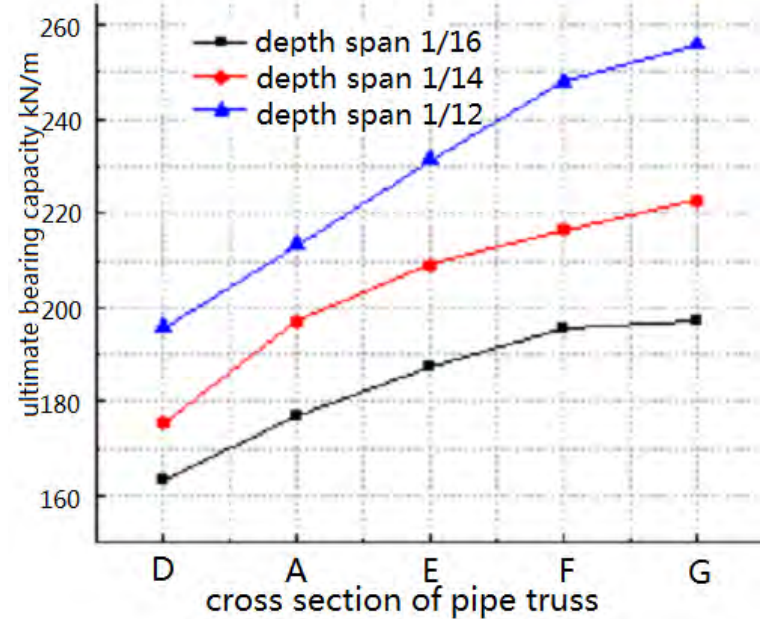

Fig. 4 Ultimate Bearing Capacity in Different Depth Span Ratios

Fig. 3 shows that the greater the cross section of pipe truss, the greater the ultimate bearing capacity, but the growth rate is not linear. The improvement of concrete strength has an obvious effect on improving ultimate bearing capacity of the composite pipe truss by increasing cross section of pipe truss, but when the concrete strength is increased to a certain level, the effect will not so obvious. 
Fig. 4 shows that with the increase of cross section of pipe truss, the greater the depth span ratio is, the more improvement of ultimate bearing capacity is. When cross section of the pipe truss increases to a certain level, the effect will not so obvious. Because excessive depth span ratio will reduce space in houses, improving depth span ratio is limited in practical application.

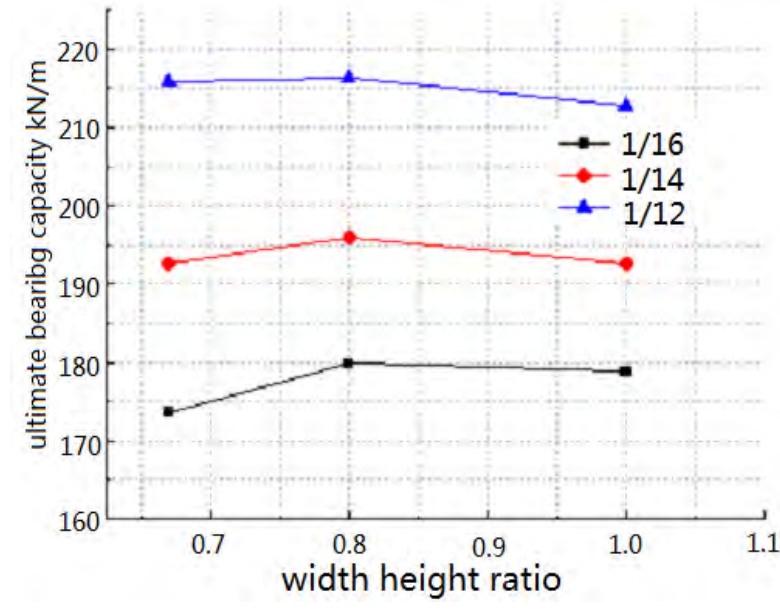

Fig. 5 Ultimate Bearing Capacity in Different Width Height Ratios

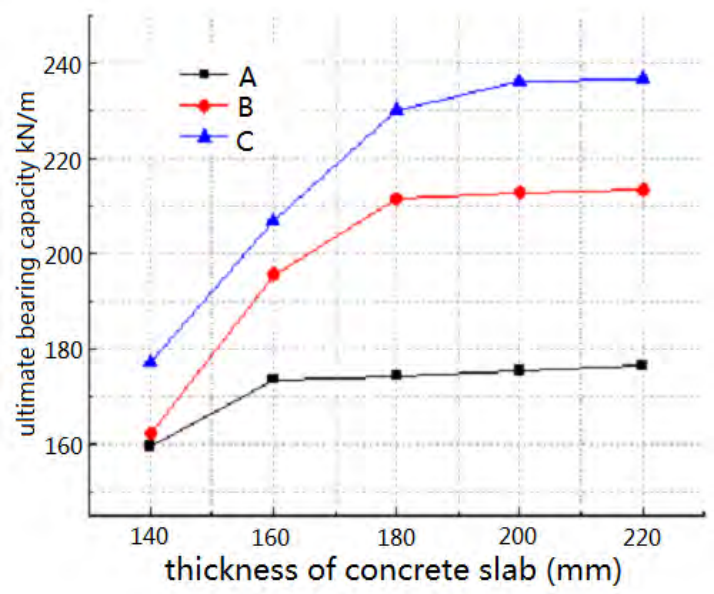

Fig. 6 Ultimate Bearing Capacity in Different Thickness of Concrete Slabs

Fig. 5 shows that increase of the width height ratio from 0.67 to 0.8 improves ultimate bearing capacity of the composite pipe truss, but increase of the width height ratio from 0.8 to 1.0 reduce ultimate bearing capacity of the composite pipe truss, so improvement of ultimate bearing capacity of the composite pipe truss cannot rely on the increase of width height ratio, and the width height ratio should not be greater than 0.8 .

Fig. 6 shows that when the concrete slab is thin, increase of the thickness improves ultimate bearing capacity of the composite pipe truss, but when the concrete slab is thick, the effect will not so obvious.

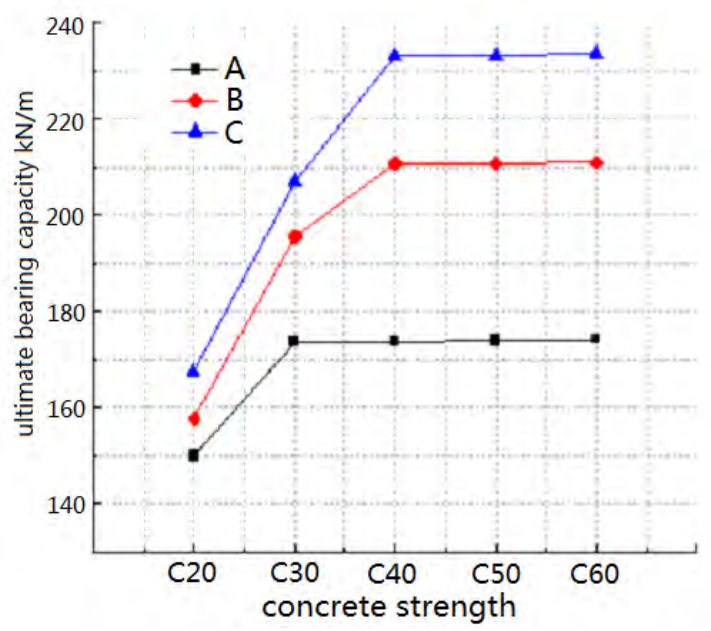

Fig. 7 Ultimate Bearing Capacity in Different Concrete Strength

Fig. 7 shows that if concrete strength is relatively low, improvement of concrete strength can significantly improve ultimate bearing capacity of the composite pipe truss, but when concrete strength is relatively high, the effect will not so obvious.

Fig. 6 and Fig. 7 show that the change point of improvement of the ultimate bearing capacity is also the change point of the failure mode of the model, that is, when abruption of the lower steel chord before crushing of the upper concrete slab, improvement of the thickness of the concrete slab and concrete strength will have an obvious effect on improvement of ultimate bearing capacity of the composite pipe truss. 


\section{Analysis of Matching Degree $\eta$}

\section{Putting Forward Matching Degree $\eta$}

Based on above analysis, the matching degree of the upper concrete slab and the lower steel chord directly affect the mechanical performance of the composite pipe truss. This paper puts forward the matching degree $\eta$ of the upper concrete slab and the lower steel chord as follows:

$$
\eta=\frac{f_{c} \times A_{c}}{f \times A}
$$

Where $f_{2} f_{\mathrm{c}}$ - the design values of the strength of the lower steel chord and the upper concrete slab, $A, A_{\mathrm{c}}$ - the cross section area of the lower steel chord and the upper concrete slab

In order to study the matching degree $\eta$, this section selects two sets of data from the cases where the upper concrete slab and the lower steel chord fail almost at the same time; bilinear interpolation method was used to get the theoretical matching degree $\eta$.

Tab. 1 Matching Degree of Cross Section A, B, C in Different Concrete Strength

\begin{tabular}{|c|c|c|c|c|c|c|}
\hline $\begin{array}{l}\text { cross } \\
\text { section of } \\
\text { pipe truss }\end{array}$ & $\begin{array}{l}\text { strength of } \\
\text { concrete } \\
\text { slab }\end{array}$ & $\begin{array}{l}\text { break load of } \\
\text { lower steel } \\
\text { chord }(\mathrm{kN} / \mathrm{m})\end{array}$ & $\begin{array}{l}\text { crushing load } \\
\text { of concrete } \\
(\mathrm{kN} / \mathrm{m})\end{array}$ & $f_{c} A c(\mathrm{kN})$ & $f A(\mathrm{kN})$ & $\begin{array}{c}\text { matching } \\
\text { degree } \eta\end{array}$ \\
\hline \multirow{2}{*}{ A } & $\mathrm{C} 20$ & 171.75 & 149.82 & 4485.12 & 5634.56 & \multirow{2}{*}{1.1521} \\
\hline & $\mathrm{C} 30$ & 173.59 & 177.06 & 6680.96 & 5634.56 & \\
\hline \multirow{2}{*}{ B } & $\mathrm{C} 30$ & 210.8 & 195.57 & 6680.96 & 6626.56 & \multirow{2}{*}{1.1737} \\
\hline & $\mathrm{C} 40$ & 210.83 & 226.74 & 8923.52 & 6626.56 & \\
\hline \multirow{2}{*}{$\mathrm{C}$} & $\mathrm{C} 30$ & 232.69 & 206.97 & 6680.96 & 7221.76 & \multirow{2}{*}{1.1604} \\
\hline & $\mathrm{C} 40$ & 233.05 & 241.04 & 8923.52 & 7221.76 & \\
\hline
\end{tabular}

Tab. 2 The Matching Degree in Different Depth Span Ratio and width Height Ratio

\begin{tabular}{|c|c|c|c|c|c|c|c|}
\hline $\begin{array}{l}\text { cross } \\
\text { section of } \\
\text { pipe truss }\end{array}$ & $\begin{array}{c}\text { break load of } \\
\text { lower steel } \\
\text { chord }(\mathrm{kN} / \mathrm{m})\end{array}$ & $\begin{array}{l}\text { crushing } \\
\text { load of } \\
\text { concrete }\end{array}$ & $f_{c} A c(\mathrm{kN})$ & $f A(\mathrm{kN})$ & $\begin{array}{l}\text { depth } \\
\text { span } \\
\text { ratio }\end{array}$ & $\begin{array}{c}\text { width } \\
\text { height } \\
\text { ratio }\end{array}$ & $\begin{array}{c}\text { matching } \\
\text { degree } \eta\end{array}$ \\
\hline $\mathrm{E}$ & 230.86 & 236.5 & 7458.88 & 6031.36 & \multirow{2}{*}{$1 / 12$} & \multirow{2}{*}{0.67} & \multirow{2}{*}{1.1779} \\
\hline $\mathrm{F}$ & 247.99 & 246.58 & 7458.88 & 6428.16 & & & \\
\hline $\mathrm{E}$ & 205.75 & 209.17 & 7527.52 & 6031.36 & \multirow{2}{*}{$1 / 14$} & \multirow{2}{*}{0.8} & \multirow{2}{*}{1.201} \\
\hline $\mathrm{F}$ & 218.93 & 216.48 & 7527.52 & 6428.16 & & & \\
\hline $\mathrm{E}$ & 191.16 & 192.07 & 7138.56 & 6031.36 & \multirow{2}{*}{$1 / 16$} & \multirow{2}{*}{0.8} & \multirow{2}{*}{1.1937} \\
\hline $\mathrm{F}$ & 207.77 & 193.5 & 7138.56 & 6428.16 & & & \\
\hline $\mathrm{F}$ & 221.88 & 224.15 & 8305.44 & 6428.16 & \multirow{2}{*}{$1 / 14$} & \multirow{2}{*}{1} & \multirow{2}{*}{1.2315} \\
\hline $\mathrm{G}$ & 239.39 & 238.25 & 8305.44 & 6824.96 & & & \\
\hline
\end{tabular}

Table 1 lists that $\eta$ ranges from 1.152 to 1.174 , there are some errors, which is because when the composite pipe truss reaches its ultimate bearing capacity, the upper concrete slab and the lower steel chord have not been within elastic stage.

Table 2 lists that when the width height ratio is 1.0, the rate in the increase of the matching degree $\eta$ is more than those in the other groups, which is consistent with above analysis, the concrete slab does not reach the ultimate strength. It validates that the width height ratio should not be greater than 0.8 .

Table 2 lists that when the width height ratio is less than 0.8 , the depth span ratio, width height ratio and concrete strength have little effect on the matching degree. In order to ensure that the failure of the lower steel chord before the crushing of the upper concrete slab, the matching degree 
$\eta=1.2$ for engineer design is given in this paper.

\section{Verification of the Matching Degree $\eta$}

In order to verify the matching degree $\eta=1.2$ for other depth span ratios, width height ratios and concrete strength, six groups finite element models and the result are listed in Table 3 and Table 4.

Tab. 3 Model Parameters

\begin{tabular}{|c|c|c|c|c|c|}
\hline number & $\begin{array}{c}\text { thickness of } \\
\text { concrete slan(mm) }\end{array}$ & concrete strength & $\begin{array}{c}\text { depth span } \\
\text { ratio }\end{array}$ & $\begin{array}{c}\text { width height } \\
\text { ratio }\end{array}$ & $f_{c A c}(\mathrm{kN})$ \\
\hline 1 & 160 & $\mathrm{C} 40$ & $1 / 12$ & 0.67 & 9962.56 \\
\hline 2 & 161 & $\mathrm{C} 40$ & $1 / 14$ & 0.67 & 9351.36 \\
\hline 3 & 162 & $\mathrm{C} 30$ & $1 / 12$ & 0.6 & 7138.56 \\
\hline 4 & 163 & $\mathrm{C} 31$ & $1 / 14$ & 0.6 & 6680.96 \\
\hline 5 & 164 & $\mathrm{C} 32$ & $1 / 15$ & 0.8 & 7321.6 \\
\hline 6 & 165 & $\mathrm{C} 33$ & $1 / 13$ & 0.8 & 7779.2 \\
\hline
\end{tabular}

Tab. 4 Results of Models

\begin{tabular}{|c|c|c|c|}
\hline number & $\begin{array}{c}\text { break load of lower } \\
\text { steel chord }(\mathrm{kN} / \mathrm{m})\end{array}$ & $\begin{array}{c}\text { crushing load of concrete } \\
(\mathrm{kN} / \mathrm{m})\end{array}$ & $\begin{array}{c}\text { displacement ductility } \\
\text { factor }\end{array}$ \\
\hline 1 & 323.56 & 324.2 & 2.8963 \\
\hline 2 & 278.93 & 280.33 & 2.9296 \\
\hline 3 & 221.29 & 222.83 & 3.0191 \\
\hline 4 & 187.78 & 190.19 & 3.0583 \\
\hline 5 & 200.72 & 200.74 & 2.9988 \\
\hline 6 & 241.06 & 247.64 & 3.1638 \\
\hline
\end{tabular}

Based on the result in Table 3.22, when $\eta=1.2$ for the design of no winding composite pipe truss, the failure modes of all models are ductile failure, and the breaking load of the lower steel chord is near to the crushing load of the upper concrete slab very much.

Above discussion proves that the matching degree $\eta=1.2$ is of engineering significance for the no winding composite pipe truss design.

\section{Conclusion}

(1) It is not an effective way to improve the stiffness and ultimate bearing capacity of the composite pipe truss by increasing the width height ratio. When the width height ratio is greater than 0.8 , it will even reduce the stiffness and ultimate bearing capacity of the composite pipe truss. Therefore the width height ratio should not be greater than 0.8 .

(2) The analysis indicates the failure mode, ductility performance and ultimate bearing capacity of the no winding composite pipe truss are affected by the matching degree of lower steel chord and the upper concrete slab directly.

(3) This paper puts forward a key parameter, matching degree $\eta$ of lower steel chord and the upper concrete slab. When $\eta=1.2$, no winding composite pipe truss will have a good mechanical performance under the commonly used depth span ratio, aspect ratio, thickness of concrete slab and the concrete strength, which can also avoid the brittle failure.

\section{References}

[1]Song Taowei, Chi Chun, Chen Wenming, Feng Yuan, Design of the Composite Grid Structure in 
the Multifunctional Training Gymnasium of Zhenjiang Sport and Exhibition Center, J. Building Structure. 40(9) (2010) 58-61.

[2]Hong Dongping, Zhao Caiqi, Du Ruinian, Li Wen, Research on Composite Floor of Steel Truss and Concrete, J. Steel Construction. 25(137) (2010) 36-39.

[3]Zhang Meifang, Reliability Analysis of Composite Space Truss, D. Shandong Jianzhu University, Jinan, 2011.

[4]JGJ 7-91, Development and Verification of Computer Program, S. China Beijing Industry Press, Beijing, 1991.

[5]N.M.Newmark, Test and Analysis of Composite Beams with Incomplete Interaction, J. Experimental Stress Analysis. 9(1) (1995).

[6]Ma Huaizhong, Wang Tianxian, Steel-concrete Composite Structure, M. China Building Materials Industry Press, Beijing, 2006.

[7]Josef Machacek, Martin Cudejko, Longitudinal Shear in Composite Steel and Concrete Trusses, J. Engineering Structures. 31(6) (2009).

[8]Shi Yiping, Zhou Yurong, Analysis of ABAQUS Structure Engineering and Detailed Examples, M. Machinery Industry Press, Beijing, 2012. 